\title{
Commonplace
}

\section{On The New}

\section{Enlightenment: Murder,}

Media, and Rebirth

Peter B. Kaufman ${ }^{1}$

${ }^{1}$ MIT Open Learning

Published on: Jul 08, 2021

License: Creative Commons Attribution 4.0 International License (CC-BY 4.0). 


\section{Murder}

When you write a book, as I have apparently done, that opens with the execution of a man by strangulation and an auto-da-fé (one man; both methods were applied more or less at the same time), $\underline{1}$ you begin to wonder about people. What is it that drives human beings to murder one another - in the name of justice, no less - especially when the victims dying on the gallows and at the stake have sought only to share knowledge and shine a brighter light upon the crimes of others? Can knowledge be shared more broadly, and more freely, without people paying the ultimate price for it?

The literature on and interest in these questions is expanding all the time, in part because of the time we're in. While my book opens in the $16^{\text {th }}$-century Reformation, with a prisoner outside Antwerp, men in our own day, everywhere, continue to hunt down other men for sharing information - seeking their exile, their imprisonment, or worse. When you stop to think about it, that's pretty weird. It's something we do. By "we" I mean people in power who organize the public spectacles of trapping Edward Snowden in airplanes and airports and Julian Assange in embassies and police vans and prisons. I also mean the victims, the subjects, the objects: that is to say, the people who get trapped and killed and sometimes kill themselves because they seek to share more knowledge and information with others. The Aaron Swartzes and Alexei Navalnys and Chelsea Mannings of the world. People who won't stop, even as they face the stoniest of punishments, because of their understanding of what is right and their commitment to progress and change.

Legal scholars and historians sometimes speak of "criminal law based on terror," a horrible oxymoron. Climactic moments in the administration of this kind of justice, public executions, in olden days often would begin with

a procession led by the city marshal on horseback, followed by the undersheriff and officers of the peace. A body of constables armed with javelins surrounded the vehicle carrying the felon. Two men clothed in black walked before the condemned. Often the sheriff, attired in a black mourning frock and black sword, rode in a special coach. With its somber dignity, the execution was intended to resemble such civic rituals as the Lord Mayor's procession. $\underline{2}$ 
Understanding this kind of inhuman societal insanity - around the sharing of knowledge in particular - is one reason why the $16^{\text {th }}$-century Actes and Monuments of these Latter and Perillous Days by John Foxe (1563), known more generally as Foxe's Book of Martyrs, was so vitally important to me as a writer writing portraits of what we do to each other. $\underline{3}$ Whatever you might think of religion, just put that thought aside, and wonder, as you read into Foxe, whether killing other people because they challenge your ideas and the restrictions you place on knowledge makes any sense. (No.)

My new book opens with the murder of translator William Tyndale, after a continental manhunt organized in large part by Thomas More. Terror eats its own, and More soon would find himself on the scaffold. Henry VIII initially wished for More to be hanged until he was half-dead, then castrated, then disemboweled and forced to watch his own intestines being burnt in front of him, and then (and only then) beheaded and burnt up whole. But on the advice of counsel he relented a bit:

About Nine [More] was brought out of the Tower; his Beard was long, his face pale and thin, and carrying a Red Cross in his Hand, he often lift up his Eyes to Heaven [. . .]. When he came to the Scaffold, it seemed ready to fall, whereupon he said merrily to the Lieutenant, Pray, Sir, see me safe up; and as to my coming down, let me shift for myself. Being about to speak to the People, he was interrupted by the Sheriff, and thereupon he only desired the People to pray for him, and bear Witness he died in the Faith of the Catholic Church, a faithful Servant both to God and the King. Then kneeling, he repeated the Miserere Psalm with much Devotion; and, rising up the Executioner asked him Forgiveness. He kissed him, and said, Pick up thy Spirits, Man, and be not afraid to do thine Office; my Neck is very short, take heed therefore thou strike not awry for having thine Honesty. Laying his Head upon the Block, he bid the Executioner stay till he had put his Beard aside, for that had committed no Treason. Thus he suffered with much Cheerfulness; his Head was taken off at one Blow, and was placed upon LondonBridge [after being boiled - and to a black mass], where, having continued for some Months, and being about to be thrown into the Thames to make room for others, his Daughter Margaret bought it, inclosed it in a Leaden Box, and kept it for a Relique. $\underline{4}$

Today, in addition to finding Foxe online, you can also obtain for yourself a copy of The Wiley Blackwell Companion to Christian Martyrdom, a collection of such accounts 
written more recently and by scholars. But of course, like much of what Wiley publishes, it's behind a paywall. $\underline{5}$

\section{Media}

Foxe knew about the power of media (he wrote 2,000 pages, after all). His focus was on the Catholic Church, which in his time was torturing and killing people who had been accused of being heretics and blasphemers. In one particularly relevant passage about the Protestant reformer Jan Hus ("I would not for a chapel of gold retreat from the truth!"; burned at the stake in 1415; he sang the Psalms as he was on fire, dying; his statue is prominent in Prague's Old Town Square), Foxe goes on about another thing firing up in the 1400s - the "divine and miraculous" invention of letterblock printing. $\underline{6}$ Its evident purpose (why God gave it to us), Foxe wrote, was precisely to expose these kinds of false convictions and unjust murders, papal clampdowns on fact, and widespread Church corruption (selling indulgences and absolutions and the like), all by "institutions most detestable":

[K]nowledge groweth, judgment increaseth, books are dispersed, the Scripture is seen, the doctors be read, stories be opened, times compared, truth discerned, falsehood detected [. . . ] all through the benefit of printing. Wherefore I suppose, that either the pope must abolish printing, or he must seek a new world to reign over: for else, as this world standeth, printing doubtless will abolish him. [T]he Pope, and all his college of cardinals, must this understand: that through the light of printing the world beginneth now to have eyes to see, and heads to judge; he cannot walk so invisible in a net, but he will be spied. $\underline{7}$

For my work on The New Enlightenment and the Fight to Free Knowledge, which covers many people trying, as Foxe puts it, "to convince darkness by light, error by truth, ignorance by learning," detailed histories of communication were also essential. The works of Robert Darnton, maestro historian of Enlightenment print culture (and former university librarian at Harvard), were indispensable. As we think about social media and video and podcasts today, and even how to regulate television and radio, it's worth underscoring how print, too, was such a promising but also volatile new technology in the $15^{\text {th }}$ century. In his newest work, which came out just after The New Enlightenment went to press, Darnton stimulates again, reminding us that "when the printed word first appeared in France in 1470," the French kings and the state more generally "did not know what to make of it." "The monarchy," he says, "reacted at first by attempting to extinguish it." Extinguish it? Echoing some of the charges of the 
Trump presidency branding media 'enemies of the people', Darnton tells us that on January 13, 1535, Francis I, king of France, "decreed that anyone who printed anything would be hanged." Period.

All quite extraordinary, in retrospect. $\underline{8}$

The work of Elizabeth Eisenstein, the great University of Michigan historian of print, was also essential. Eisenstein reminds us how printing and print culture grew so fast that it seemed to become part of our world almost naturally and invisibly. Thirty years after Johannes Gutenberg built the first printing workshop in Germany, that country had printing shops in only forty towns. By 1500, a thousand printing presses were in operation in Western Europe, and they had produced roughly 8 million books. But by the end of that century, between 150 and 200 million books were circulating. The ubiquity of text today - words and writing are now everywhere in our everyday lives has helped to render the centrality of printing, the magical, mechanical duplication of word and image, more of an "unacknowledged revolution" than a violent one: what Eisenstein calls an "elusive transformation." It was hard to sense at the time, but it was happening. $\underline{9}$

Yet no one scholar of media can be more inspiring than Walter J. Ong, the Jesuit historian - and philosopher - from St. Louis University. In his books and essays, Ong tells us that we have been through essentially three phases in our communications development, what he calls "three transformations of the word." The first stage, which governed most of human existence, was that of "the unrecorded word," oral and aural culture. The second stage, "the denatured word," was the period that began first with the alphabet and then grew to include printing. The third stage, where we find ourselves today, is the electronic age of the modern sensorium. As a historian, Ong presses us to develop a deeper understanding and appreciation of the "normal oral or oral-aural consciousness" and original "noetic economy" of humankind. Homo sapiens have been around for some 30,000 years, but the oldest script not even six thousand; the alphabet, less than four. Mesopotamian cuneiform dates from 3,500 BC, the original Semitic alphabet to only around 1,500 BC, and the number of world languages with enough writing at their core to have produced a literature, just over 100. "Only after being on earth some 500,000 years (to take a fairly good working figure) did man move from his original oral culture, in which written records were unknown and unthought of, to literacy." As a sage and a prophet, Ong tells us, in cryptic and koanic ways that may be meaningful to readers of the Commonplace and fans of the 
Knowledge Futures Group, "If knowledge is power, knowledge of how to generate knowledge is . . . power over power." $\underline{10}$

Finally, to more deeply understand the structure of print communication, there is Anthony Grafton, the Princeton historian. In The New Enlightenment I cite Grafton's work several times, but especially in discussions of the literary culture under totalitarianism in the Soviet bloc. Grafton tells us, for example, how in East Germany, among the most repressive of $20^{\text {th }}$-century Soviet-backed regimes, certain historians would make special "statements of intellectual centrality and allegiance" by putting the works of Marx and Engels out of alphabetical order at the start of their lists of bibliographic citations. Such signaling! Imagine? Grafton reminds us how citation and verification are at the heart of healthy media in functioning society. "Only the use of footnotes and the research techniques associated with them," Grafton writes, "makes it possible to resist the efforts of modern governments, tyrannical and democratic alike, to conceal the compromises they have made, the deaths they have caused, the tortures they or their allies have inflicted," which is sort of where this essay started. 11 This is what, in part, the French Encyclopédie at heart of the original Enlightenment was about, what Wikipedia is about today, and what the central challenge is going to be for the video age in front of us. This challenge is at the core of something I am writing now, under contract with MIT Press, about the power of video in our electronic age, and about the necessity we now face to find a method of citation and verification, in our extended disinformation crisis, for the $21^{\text {st }}$-century world of film and sound.

\section{Rebirth}

Why are we such savages to one another? Who can say? We are weird. Michael Massing, who used to write at length about the failures of contemporary journalism, has written a new history of the time of Foxe and Tyndale; he reminds us of the violence of everyday life then and now. "Clubbings, slashings, stabbings, assaults, and rapes were routine occurrences in the late Middle Ages. [. . .] The law itself was pitiless [. . . .] A Salzburg municipal ordinance stipulated that 'a forger shall be burned or boiled to death. A perjurer shall have his tongue torn out by the neck. . .'" And as for organized religion, fuhgeddabout it:

Nearly every church in northern Europe had an image of the crucifixion featuring nails, thorns, spears, whips, and dripping blood, while tableaux of the saints showed them undergoing ghastly forms of martyrdom. $\underline{12}$ 
But if our most barbarous qualities might be related to ignorance, there is reason for hope - some of it in the libraries and archives. As we think about our current political and social turmoil - a disinformation crisis; 4 million dead from Covid; economic dislocations rocking the world; political violence and brute ignorance at work in our capitols - we should remember the days when foundations and universities came together to underwrite massive projects to examine, but really systematically examine, why so much balderdash is in the air, why there are so many problems in our communications infrastructure, and how best to fix them. One such effort was in the 1960s, when the Carnegie Corporation of New York underwrote the work of a national commission over several years to study and recommend improvements to the world of what was then called educational television. The Carnegie Commission was chaired by James Killian, the former president of MIT, and James Killian's papers are in the archives of the MIT Libraries. $\underline{13}$ Today work by a new commission headed by the Aspen Institute and underwritten by philanthropist Craig Newmark is under way to look at our current issue of truth decay and information disorder and what to prescribe for it. The recordings of these interviews and deliberations are already going up online. $\underline{14}$ Much more of course needs to be done.

But - that's what we're here for.

\section{Footnotes}

1. Peter B. Kaufman, The New Enlightenment and the Fight to Free Knowledge (New York: Seven Stories Press, 2021), available free at: https://newenlightenment.pubpub.org $/ . \oplus$

2. Steven Wilf, "Imagining Justice: Aesthetics and Public Executions in Late Eighteenth-Century England," Yale Journal of Law and the Humanities 5, No. 1 (1993), available free at: https://digitalcommons.law.yale.edu/yjlh/vol5/iss1/3/.

3. https://www.dhi.ac.uk/foxe/. See also: https://en.wikipedia.org/wiki/Foxe\%27s Book of Martyrs..

4. Quoted in Kaufman, The New Enlightenment, pp. 16-17.

5. Paul Middleton, ed., The Wiley Blackwell Companion to Christian Martyrdom (Hoboken, New Jersey: John Wiley \& Sons Ltd., 2020), at: https://www.wiley.com/en- 
us/Wiley+Blackwell+Companion+to+Christian+Martyrdom-p-9781119100027. 6. "To ensure that nothing remained that could become a relic [the $16^{\text {th }}$ century saw a brisk trade in human body body parts as souvenirs and totems], his skull was smashed, his heart was burned through, and his garments were fed to the flames." Michael Massing, Fatal Discord: Erasmus, Luther, and the Fight for the Western Mind (New York: HarperCollins, 2018), p. 367. $\_$

7. There are woodcuts of people hurrying to gather firewood to burn Hus alive while Hus watches them, roped to the stake. One thinks about the prints watching Assange hustled into police vans or screening documentary footage of Snowden hiding out in Hong Kong. Foxe remarks how "the bishop of Rome, with all the whole and full consent of the cardinals, patriarchs, archbishops, bishops, abbots, priors, lawyers, doctors, provosts, deans, archdeacons, assembled together in the council on Constance, had condemned poor John Huss and Jerome of Prague to death for heresy, notwithstanding they were no heretics [. . ]." https://www.dhi.ac.uk/foxe/. 8.

Robert Darnton, Pirating and Publishing: The Book Trade in the Age of Enlightenment

(New York: Oxford University Press, 2021), p. 13. See also: Darnton, The Business of Enlightenment: A Publishing History of the Encyclopédie, 1775-1800 (Cambridge, MA: Harvard University Press, 1979); Darnton, The Literary Underground of the Old Regime (Cambridge, MA: Harvard University Press, 1982); Darnton, George Washington's False Teeth: An Unconventional Guide to the Eighteenth Century (New York: W. W. Norton, 2001); and Darnton, Censors at Work: How States Shaped Literature (New York: W. W. Norton, 2015). $\leftrightarrows$

9. Elizabeth L. Eisenstein, The Printing Press as an Agent of Change: Communications and Cultural Transformations in Early Modern Europe (Cambridge: Cambridge University Press, 1979), p. 1. Also Lucien Febvre and Henri-Jean Martin, The Coming of the Book: The Impact of Printing 1450-1800 (New York: Verso, 1976); and "Global Spread of the Printing Press," Wikimedia Foundation, https://en.wikipedia.org/wiki/Global spread of the_printing_press. $\bullet$ 10. Walter J. Ong, S.J., "Knowledge in Time," in Ong, ed., Knowledge and the Future of Man: An International Symposium (New York: Holt. Rinehart \& Winston, 1968), p. 25, ellipses added. See also: Walter J. Ong, S.J., The Presence of the Word: Some 
Prolegomena for Cultural and Religious History (New Haven: Yale University Press, 1967); Ong, Orality and Literacy: The Technologizing of the Word (New York: Routledge, 1982); and Ong, "Writing is a Technology that Restructures Thought," in Gerd Baumann, ed., The Written Word: Literacy in Transition (Wolfson College Lectures 1985) (Oxford: Clarendon Press, 1986), pp. 23-50. See also Paul Starr, The Creation of the Media: Political Origins of Modern Communications (New York: Basic Books, 2004). $\doteq$

11. "Only the use of footnotes enables historians to make their texts not monologues but conversations, in which modern scholars, their predecessors, and their subjects all take part." Anthony Grafton, The Footnote: A Curious History (Cambridge: Harvard University Press, 1997), pp. 11, 233-234.

12. Massing, Fatal Discord, p. 25.

13. Carnegie Commission on Educational Television, Public Television: A Program for Action: The Report of the Carnegie Commission on Educational Television (New York: Bantam Books, 1967). The MIT Library Archives hold President Killian's papers from the commission; see "James R. Killian Papers," MIT Archives Space, MIT Libraries, https://archivesspace.mit.edu/repositories/2/resources/916. The papers of the Carnegie Commission itself are deposited in the Wisconsin Historical Society's Mass Communications History Collection. See "About Our Mass Communications History Collection," Wisconsin Historical Society, https://www.wisconsinhistory.org/Records/Article/CS4017; and "Carnegie Commission on Educational Television Records, 1963-1967," University of Wisconsin Digital Collections, http://digicoll.library.wisc.edu/cgi/f/findaid/findaid-idx? $\underline{\mathrm{c}=\text { wiarchives}} ; \underline{\mathrm{view}=\text { reslist}} ; \underline{\text { subview }=\text { standard }} ; \underline{\text { didno }=\mathrm{uw} \text {-whs- }}$ $\underline{\text { us0145af; focusrg }} \underline{\underline{n}=\text { contentslist}} ; \underline{\mathrm{cc}=\text { wiarchives}} ; \underline{b} y \underline{t e}=507708481$. The two chapters in my book are freely licensed and available to read and download online: https://new-enlightenment.pubpub.org/pub/37bpvjpo/release/1 and https://newenlightenment.pubpub.org/pub/hzzfjlu4/release/1.

14. https://www.aspeninstitute.org/programs/aspen-commission-on-informationdisorderl.. 